DOI (Article): https://doi.org/10.31108/2.2020.4.21.6

УДК 159.9.07.923-055.2:336.74

\title{
Клименко Наталія
}

\section{КОМПЛЕКС МЕТОДИК ДЛЯ ДОСЛІДЖЕННЯ ОСОБИСТІСНО- ПРОФЕСІЙНИХ СТИЛІВ ПОВЕДІНКИ ЯК ЧИННИКА СТАВЛЕННЯ ЖІНОК ДО ГРОШЕЙ}

\begin{abstract}
Клименко Наталія. Комплекс методик для дослідження особистісно-професійних стилів поведінки як чинника ставлення жсінок до грошей.

Вступ. Дослідження проблеми впливу особистісно-професійних стилів поведінки жінок на ӥх ставлення до грошей, що є важливим у контексті економічної соиіалізації жінок та їх активного включення в соиіальне та професійне життя, потребує, зокрема, розробки комплеку методик для вивчення особистісно-професійних стилів поведінки як чинника ставлення жінок до грошей.

Мета дослідження. Розробка комплексу методик для дослідження особистісно-професійних стилів поведінки як чинника ставлення жінок до грошей.

Результати дослідження. Розроблено комплекс методик, який складається з трьох груп: а) методики для вивчення монетарних установок особистості; б) методики для вивчення особистіснопрофесійних стилів жінок; в) методики для вивчення гендерних, сочіально-демографічних, організачійно-професійних та сочіально-економічних чинників, які впливають на ставлення жінок до грошей та на використання ними особистісно-професійних стилів.
\end{abstract}

Висновки. Проаналізований комплекс методик може бути використаний для проведення діагностики особистісно-професійних стилів поведінки як чинника ставлення жінок до гротей.

Ключові слова: ставлення жінок до грочей, монетарні установки особистості, переважаючі стилі ставлення особистості до грошей, установки «праия-гроші», особистісно-професійні стилі поведінки, життєві позииії особистості, особистісні стилі взаємодії з іншими людьми, стилі поведінки y професійній діяльності, чинники, що впливають на ставлення до грошей, методики для дослідження ставлення до громей, методики для дослідження особистісно-професійних стилів поведінки жінок.

Клименко Наталья. Комплекс методик для исследования личностно-профессиональных стилей поведения как фактора отношение женщин к деньгам.

Введение. Исследование проблемы влияния личностно-профессиональных стилей поведения женщин на их отношение к деньгам, что важно в контексте экономической социализации женщин и их активного включения в сочиальную и профессиональную жизнь, требует, в частности, разработки комплекса методик для изучения личностно-профессиональных стилей поведения как фактора отношения женщин к деньгам.

Цель исследования. Разработка комплекса методик для исследования личностнопрофессиональных стилей поведения как фактора отношения женщин к деньгам.

Результаты исследования. Разработан комплекс методик, состоящий из трех групп: а) методики для изучения монетарных установок личности; б) методики для изучения личностнопрофессиональных стилей женщин; в) методики для изучения гендерных, соииально-демографических, организационно-профессиональных и сочиально-экономических факторов, влияющих на отномение женшин к деньгам и на использование личностно-профессиональных стилей.

Выводы. Проанализированный комплекс методик может быть использован для проведения диагностики личностно-профессиональных стилей поведения как фактора отнотение женщин $\kappa$ деньгам.

Ключевые слова: отночение женщин $к$ деньгам, монетарные установки личности, преобладающие стили отномения личности к деньгам, установки «труд-деньги», личностнопрофессиональные стили поведения, жизненные позиции личности, личностные стили взаимодействия с другими людьми, стили поведения в профессиональной деятельности, факторы, влияютие на отношение к деньгам, методики для исследования отношения к деньгам, методики для исследования личностно-профессиональных стилей поведения женщин. 
Вступ. Інтенсивні соціально-економічні трансформаційні процеси світового рівня вимагають від людини швидкої адаптації до постійних змін та активного способу життя. Важливою складовою функціонування будь-якого суспільства $є$ гроші. Ставлення до грошей впливає на самооцінку, спосіб життя та реалізацію власних професійних та економічних потреб особистості. Жінки, яких традиційно називають «берегинями родинного вогнища» та «дарувальницями життя», в умовах сьогодення не обмежуються лише цими двома ролями. Вони активні члени соціально-економічного життя країни: очільниці державних, комерційних та громадських організацій, держслужбовці та науковці.

Ставлення жінок до грошей особливо важливе, адже низький рівень монетарної грамотності жінок у наш час негативно впливає на їхню адаптацію до соціально-економічних змін. Осмислення цієї проблеми потребує визначення методик для дослідження особистіснопрофесійних стилів поведінки як чинника ставлення жінок до грошей.

Проблеми психології грошей знайшли відображення в роботах, присвячених вивченню різних чинників, що впливають на ставлення до грошей, сутності грошей, їх роль в економічній соціалізації особистості, ставлення до грошей різних соціальних груп, ставлення до грошей персоналу комерційних організацій тощо. Дослідження представлені в роботах як зарубіжних (Furnham, \& Argyle, 1998; Tang, 1993 та ін.) так і вітчизняних (Зубіашвілі, 2007, 2009; Карамушка, \& Ходакевич, 2012, 2017; Паршак, 2018, 2020; Сімків, 2011, 2012, 2014 та ін.) вчених. Що до дослідження особистісно-професійних стилів поведінки, то слід зазначити, що дослідження окремих аспектів особистісно-професійних стилів знайшли відображення в роботах зарубіжних (Берн, 1999; Стюарт, \& Джойнс, 1996; Харріс, 2020; Дж. Хей, 2020; та ін.) та вітчизняних (Горностай, 2007; Костіна, 2011 та ін.) авторів.

Разом із тим, практично не дослідженою є проблема впливу особистісно-професійних стилів поведінки жінок на їх ставлення до грошей. Зокрема, не дослідженою є проблема розробки комплексу методик для вивчення особистісно-професійних стилів поведінки як чинника ставлення жінок до грошей.

Мета дослідження: розробити комплекс методик для дослідження особистіснопрофесійних стилів поведінки як чинника ставлення жінок до грошей.

Результати дослідження та їх обговорення. На основі аналізу літератури нами було підібрано «Комплекс методик для дослідження особистісно-професійних стилів поведінки як чинника ставлення жінок до грошей», який включає три групи методик, що були виділені та проаналізовані нами (табл. 1). Комплекс включає три групи методик. Першу групу складають методики для вивчення ставлення жінок до грошей. До другої групи входять методики для дослідження особистісно-професійних стилів жінок. Третя група методик спрямована на вивчення соціально-демографічних, організаційно-професійних, соціальноекономічних та гендерних чинників, які впливають на ставлення жінок до грошей.

У першій групі виділено методики для: а) визначення монетарних установок особистості; б) дослідження переважаючого типу ставлення до грошей; в) вивчення соціальнопсихологічних установок особистості у сфері мотивацій і потреб. До складу другої групи входять методики для: а) дослідження життєвої позиції особистості; б) вивчення особистісних стилів взаємодії з іншими людьми; в) вивчення стилів поведінки у професійній діяльності. До третьої групи належать методики для: а) вивчення гендерного типу жінок; б) вивчення соціально-демографічних, організаційно-професійних та соціально-економічних чинників.

Проаналізуємо послідовно кожну із груп методик. до грошей.

Розпочнемо $з$ першої групи методик, які спрямовані на вивчення ставлення жінок 
Комплекс методик для дослідження особистісно-професійних стилів поведінки як чинника ставлення жінок до грошей

\begin{tabular}{|c|c|}
\hline Назва методик & Показники, що досліджуються \\
\hline \multicolumn{2}{|c|}{ 1. Методики для вивчення ставлення жінок до грошей: } \\
\hline \multicolumn{2}{|c|}{ 1.1. Методики для вивчення монетарних установок особистості: } \\
\hline $\begin{array}{lrr}\text { Методика А. Фернема «Шкала } \\
\text { грошовий } & \text { переконань } \\
\text { поведінки» } & \text { (MBBS) } \\
\text { (модифікований } & \text { варіант } \\
\text { Сімків) (Сімків, 2012) }\end{array}$ & $\begin{array}{l}\text { Рівні враженості ставлення людини до грошей відповідно } \\
\text { до } 4 \text { типів грошових настановлень: грошова одержимість; } \\
\text { влада; економність; неадекватна поведінка з грошима }\end{array}$ \\
\hline \multicolumn{2}{|c|}{ 1.2. Методики для вивчення переважаючого типу ставлення до громей: } \\
\hline 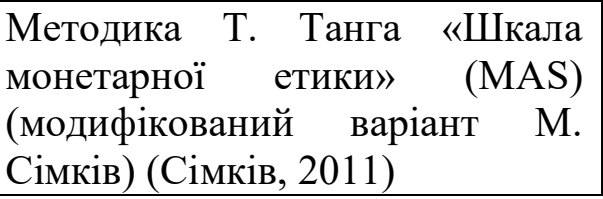 & $\begin{array}{l}\text { Рівні враженості грошових установок за } 6 \text { шкалами: гроші } \\
\text { як благо; гроші як зло; гроші як засіб досягнення успіху; } \\
\text { гроші як чинник поваги до людей; планування видатків; } \\
\text { гроші як засіб досягнення свободи та влади }\end{array}$ \\
\hline \multicolumn{2}{|c|}{ 1.3. Методики для дослідження установок «праия-громі»: } \\
\hline 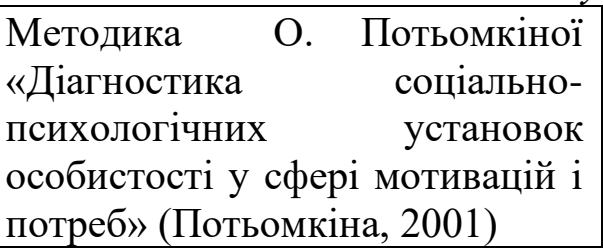 & $\begin{array}{l}\text { Рівні враженості соціально-психологічних установок } \\
\text { особистості у сфері мотивацій і потреб: «процес - } \\
\text { результат», «альтруїзм - егоїзм»; «праця - гроші», «влада } \\
\text { - свобода» }\end{array}$ \\
\hline \multicolumn{2}{|c|}{ 2. Методики для вивчення особистісно-професійних стилів жінок: } \\
\hline \multicolumn{2}{|c|}{ 1.3. 2.1. Методики вивчення життевої позииії особистості: } \\
\hline $\begin{array}{l}\text { Опитувальник Дж. Хей «Вікна } \\
\text { у світ» (Хей, 2020) }\end{array}$ & $\begin{array}{l}\text { Рівні враженості різних комбінацій життєвих позицій } \\
\text { особистості, які є базовими світоглядними моделями } \\
\text { ставлення людини як до себе, так і до інших }\end{array}$ \\
\hline \multicolumn{2}{|c|}{ 2.2. Методики вивчення особистісних стилів взаємодї̈ з іншими людьми: } \\
\hline 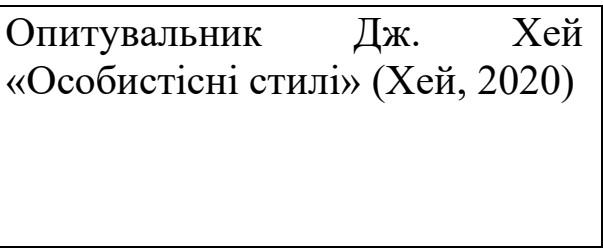 & $\begin{array}{l}\text { Рівні враженості внутрішніх Его-станів людини, які } \\
\text { втілюються в особистісних стилях поведінки людин, } \\
\text { таких як: «Батько-Контролер», «Батько-Вихователь», } \\
\text { «Функціональний Дорослий», «Адаптивна дитина» та } \\
\text { «Природна дитина» }\end{array}$ \\
\hline \multicolumn{2}{|c|}{ 2.3.Методики вивчення стилів поведінки у професійній діяльності: } \\
\hline $\begin{array}{l}\text { Опитувальник Дж. Хей «Робочі } \\
\text { стилі» (Хей, 2020) }\end{array}$ & $\begin{array}{l}\text { Рівні враженості внутрішніх «драйверів», які формують } \\
\text { «Робочі стилі» поведінки людини } 3 \text { відповідними } \\
\text { характеристиками: («Поспішай», «Будь досконалим», } \\
\text { «Радуй інших», «Намагайся», «Будь сильним» }\end{array}$ \\
\hline \multicolumn{2}{|c|}{$\begin{array}{l}\text { 3. Методики для вивчення гендерних, соціально-демографічних, організаційно- } \\
\text { професійних, соціально-економічних чинників, які впливають на ставлення жінок до } \\
\text { грошей та використання ними особистісно-професійних стилів: }\end{array}$} \\
\hline \multicolumn{2}{|c|}{ 3.1. Методики для вивчення гендерного типу особистості: } \\
\hline $\begin{array}{llr}\text { Методика } & \text { С. } & \text { Бем } \\
\text { (модифікований } & \text { варіант О. Г. } \\
\text { Лопухової } & \text { «Маскулінність, } \\
\text { фемінність та } & \text { гендерний тип } \\
\text { особистості») (Лопухова, 2003) }\end{array}$ & $\begin{array}{l}\text { Рівні враженості маскулінності та фемінності, а також для } \\
\text { визначення психологічної статі особистості }\end{array}$ \\
\hline
\end{tabular}




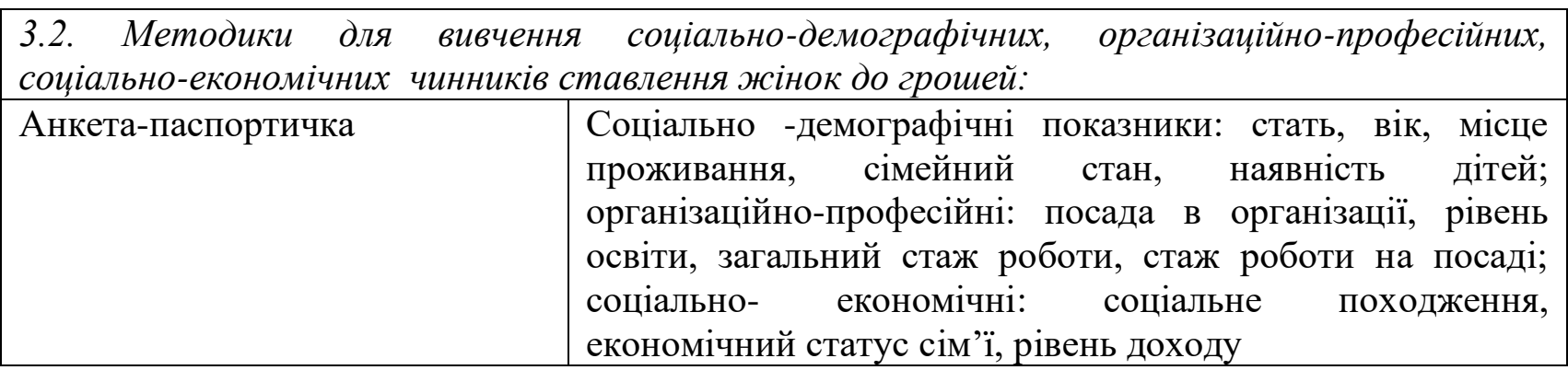

А. Фернем (1998) застосував дану методику для дослідження детермінант грошових уявлень та грошової поведінки. Після проведення дослідження на основі факторного аналізу даних автором було виділено шість типів грошових настановлень: 1) обсесія; 2) влада/витрати; 3) збереження; 4) безпека/консервативність; 5) недостатність; 6) зусилля/здатності.

М. Сімків (2012) було проведено модифікацію даної методики. Текст методики «Шкала грошових уявлень та поведінки» був перекладений українською мовою та відредагований. У процесі перекладу були враховані морфологічні та синтаксичні особливості української мови та особливості української психологічної термінології. Унаслідок цього формулювання деяких тверджень були змінені. Проте основний зміст кожного твердження збережений.

Авторський варіант методики передбачає оцінювання кожного твердження за семибальною шкалою. В модифікованому варіанті методики М. Сімків (2012), для кращого розуміння респондентами процедури оцінювання, використовується п'ятибальна шкала: 1 повністю незгідний; 2 - незгідний; 3 - займаю нейтральну позицію; 4 - згідний; 5 - повністю згідний. У процесі проведення аналізу змістової валідності ряд тверджень були вилучені із загального списку. Таким чином, модифікований варіант методики складається з 47 тверджень, що відображають 4 типи грошових настановлень: 1) грошова одержимість; 2) влада; 3) економність; 4) неадекватна 3 поведінка грошима.

До фактора «Грошова одержимість» входить 15 тверджень, що відображають постійні думки людини про гроші, переживання за своє фінансове становище та небажання обговорювати його з іншими.

До другого фактора «Влада» увійшло 8 тверджень, які відображають ставлення людини до грошей як до засобу отримання контролю над іншими людьми. Гроші також забезпечують їм відчуття власної переваги та значущості.

Третій фактор «Економність» містить 12 тверджень. Зміст цих тверджень свідчить про економне ставлення людини до грошей, небажання їх витрачати.

Четвертий фактор «Неадекватна поведінка з грошима» містить 12 тверджень, що характеризують неадекватне ставлення та поведінку людини щодо грошей. Отже, чотири фактори модифікованого варіанта методики відображають різне ставлення людини до грошей.

Призначення даної методики у підібраному нами комплексі методик полягає в тому, що вона дає можливість виявити монетарні установки особистості, які формуються в результаті накопичення досвіду поводження з грошима та взаємодії з іншими людьми з приводу грошей.

Наступна методика нашого дослідження призначена для вивчення переважсаючого типу ставлення до грошей.

Для дослідження переважаючого типу ставлення жінок до грошей буде використано методику Т. Танга «Шкала монетарної етики” (MAS) (модифікований варіант М. Сімків) (Сімків, 2011).

Т. Танг (1993) створив методику для вимірювання грошових установок «Шкала грошової (монетарної) етики» (Money Ethic Scale). Спочатку методика налічувала 50 тверджень, але після проведення дослідження, список скоротився до 30 тверджень. Т. Танг (1993) після проведення факторного аналізу виділив 6 основних факторів. Методика показала високу внутрішню надійність. 
Отже, на думку Т. Танга (1993), грошові установки особистості складаються 3 трьох компонентів: 1) афективного (гроші як добро чи зло); 2) когнітивного (гроші як засіб досягнення свободи і влади; гроші як чинник поваги до людини); поведінкового (ставлення до планування грошових видатків).

У процесі модифікації даної методики М. Сімків (2011) методику було перекладено українською мовою та відредаговано експертами. У ході роботи над україномовним перекладом тексту методики були дещо змінені формулювання тверджень та уточнені назви шкал, оскільки існують певні особливості в україномовній психологічній термінології та в українській мові взагалі. Проте основний зміст кожного твердження було збережено. Була запропонована інструкція до методики та інтерпретація всіх шкал.

Перша шкала отримала назву «Гроші як благо». До цієї шкали увійшло 9 тверджень, які свідчать про позитивне ставлення людини до грошей. Людина наділяє гроші великою цінністю та вважає їх важливим фактором у своєму житті.

Друга шкала «Гроші як зло» налічує 6 тверджень, що свідчать про негативну грошову установку, ставлення до грошей як до кореня всього зла, як до непотрібної речі.

Третя шкала має назву «Гроші як засіб досягнення успіху». До цієї шкали увійшло 4 твердження, зміст яких свідчить про те, що гроші для людини стають засобом досягнення особистого успіху, вони є життєвою метою.

Четверта шкала «Гроші як чинник поваги до людей» містить 4 твердження, які відображають ставлення людини до грошей як засобу примноження друзів $\mathrm{i}$ можливості проявити власну компетентність за здібності. Гроші гідні пошани, та завдяки їм людей поважають у спільноті.

Шкала п’ять «Планування видатків» містить 3 твердження, що стосуються поведінкового компонента грошових установок. Тобто людина ретельно планує свій бюджет, вчасно оплачує всі рахунки та обережно витрачає гроші.

Остання шоста шкала «Гроші як засіб досягнення свободи та влади» містить 4 твердження, які відображають ставлення людини до грошей як засобу досягнення свободи та влади. Гроші символізують силу, яка дає можливість людині бути тим, ким вона хоче.

Ця методика пройшла процедуру стандартизації даних та витримала перевірку на надійність (Сімків, 2011).

Методики А. Фернема «Шкала грошовий переконань та поведінки» (MBBS) (модифікований варіант М. Сімків) у підібраному нами комплексі методик призначена для дослідження переважаючого типу ставлення жінок до грошей.

Проведемо аналіз методики для дослідження установок «праця-гроші».

Для дослідження установок «праця-гроші» в контексті соціально-психологічних установок жінок використовуватиметься «Методика діагностики соціально-психологічних установок особистості в сфері мотивацій та потреб» О. Потьомкіної (2001). Методика складається 380 питань: 40 питань спрямовані на виявлення ступеня прояву соціальнопсихологічних установок «процес - результат», «альтруїзм - егоїзм»; 40 питань спрямовані на виявлення ступеня прояву соціально-психологічних установок «праця - гроші», «влада свобода».

Дослідження ступеня прояву соціально-психологічних установок «процес - результат», «альтруїзм - егоїзм» у жінок може надати нам наступні дані.

«Oрієнтація на процес». Люди орієнтовані на процес часто запізнюються зі здачею роботи, їх процесуальна спрямованість перешкоджає їх результативності. Вони менше замислюються над досягненням результату. Отже, можемо припустити, що при побудові професійної кар'єри такі люди можуть не досягати бажаного успіху. Така орієнтація може також впливати на їх фінансове становище.

«Oрієнтація на результат». Люди, що орієнтуються на результат можуть проявляти активну поведінку у досягнені поставлених цілей в тому числі і фінансових. Досягати 
результату в будь-якій діяльності всупереч суєті, перешкод, невдач.

«Oрієнтація на альтруїзм». Люди, які орієнтуються на альтруїстичні цінності, часто на шкоду собі, проте заслуговують на повагу. Вони з відкритим серцем відгукуються на прохання про допомогу. Вони можуть поділитися останнім, що в них $\epsilon$.

«Oрієнтація на егоїзм». Відсутність егоїзму може нашкодити людині, як і надмірний альтруїзм. Невеличка частка «розумного егоїзму» йде людині на користь і допомагає зберегти власні кордони. Проте люди з надмірно вираженим егоїзмом зустрічаються не так часто.

Щодо дослідження соціально-психологічних установок «свобода влада», «праия гроші» методика має наступні шкали.

«Орієнтація на праџю». Люди, які орієнтуються на працю, увесь свій час використовують для того, щоб щось зробити. Іноді вони не мають вихідних і відпусток. Вони отримують задоволення у праці. Люди 3 такою працездатністю можуть досягати великих професійних успіхів, але їм слід бути обережними і не потрапити до пастку трудоголізму.

«Орієнтація на свободу». Такі люди обирають головною цінністю свободу. Слід зазначити, що часто орієнтація на свободу поєднується з орієнтацією на працю, рідше це поєднання «свободи» і «грошей».

«Орієнтація на владу». Існує думка, що ця орієнтація більше властива чоловікам. Для цих людей провідною цінністю $є$ вплив на інших.

«Oрієнтація на гроші». Зазвичай буває в двох випадках, коли гроші є і коли їх немає. Провідна цінність - збільшення своїх статків.

У нас час суспільних трансформаційних перетворень відбувається зміна цінностей $\mathrm{i}$ усталених поглядів на життя, тому дослідження соціально-психологічних орієнтацій особистості має важливе зазначення. «Методика діагностики соціально-психологічних установок особистості в сфері мотивацій та потреб» О.Ф. Потьомкіної (2001), яку ми застосовуємо в комплексі методик нашого дослідження, призначена для дослідження установок «праця-гроші» в контексті соціально-психологічних установок жінок.

Далі розглянемо другу групу методик, які дають можливість дослідити особистіснопрофесійні стилі жінок.

У цій групі першою проаналізуємо методику для вивчення жситтєвої позиції особистості.

Дослідження життєвої позиції жінок буде здійснено за допомогою опитувальника Дж. Хей «Вікна у світ» (Дж. Хей, 2020).

Життєві позиції Е. Берн (1999) визначав як екзистенційні позиції, або ставлення людини до світу, у якому вона живе (Дж. Хей, 2020). Т. Харріс (2020) називає їх «установками життя».

Отже, життєва позиція - це стійка, внутрішньо усвідомлена система поглядів людини на життя як концепцію, на свою діяльність, а також система ставлень іiї до суспільства, до самої себе, зумовлена об'єктивним становищем людини у визначеній системі суспільних відносин. Водночас, життєва позиція є одним із способів соціалізації особистості, iї своєрідною соціальною інтеграцією (Стюарт, \& Джойнс, 1996).

Фахівці з транзакційного аналізу стверджують, що в основі життєвого сценарію людини лежить життєва позиція індивіда. Життєва позиція, виступаючи одним з основних регуляторів соціальної поведінки в конкретних умовах, забезпечує перспективу життєвого шляху і розвитку індивідуальності людини (Стюарт, \& Джойнс, 1996).

Отже, об'єднавши всі можливі комбінації екзистенційних позицій, визначених Е. Берном (1999), отримуємо чотири життєвих установки стосовно себе та інших: 1) «Я не в порядку, Ви в порядку» («Я не ОК - Ви ОК»); 2) «Я не в порядку, Ви не в порядку» («Я не ОК - Ви не ОК»); 3) «Я в порядку, Ви не порядку» («Я ОК - Ви не ОК»); 4) «Я в порядку, Ви в порядку» («Я ОК Ви ОК») (Харpic, 2020).

Можливі комбінації життєвих позицій Дж. Хей (2020) розглядає у вигляді простої матриці як набір вікон, через які люди дивляться на світ. Дж. Хей (2020) додає до цієї концепції 
п’яте вікно, яке, на їі думку, чисте від викривлень сприйняття «Я, Ти» - це «відчинене вікно».

На основі теорій транзакційного аналізу, зокрема концепції життєвих позицій, Дж. Хей (2020) розробила опитувальник «Вікна у світ». Опитувальник складається з 9 розділів, кожний 3 них має по 4 твердження. 3 чотирьох тверджень необхідно обрати лише одне. Після обробки результатів опитувальник пропонує намалювати гістограму - індивідуальний профіль особистості за чотирма шкалами: «Переможець-Переможець» («Впевнений»); «Той, що програв - Переможець» («Послужливий»); «Переможець - той, що програв» («Агресивний»); «Той, що програв - Той, що програв» («Байдужий»).

«Переможець - Переможець» (Впевнений) («Я ОК - Ви ОК») - включення у взаємодію: «Здорова позиція». Ця позиція базується на реальності. Людина бере участь у житті та розв'язанні життєвих проблем. Діє з метою досягнення бажаних для неї виграшних результатів. Реалізує творчий підхід до вирішення завдань.

«Той, щзо програв - Переможець» («Послужливий») («Я не ОК - Ви ОК») - вихід із взаємодії: «Депресивна позиція». Людина почувається «нижче», ніж інші люди. Несвідомо вона буде обирати неприємні для неї почуття і поведінкові прояви, які «стверджуватимуть», що своє місце у житті вона визначає правильно. Людина ніби не має прав, завжди є люди, які мають більше прав, ніж вона.

«Переможець - Той, щзо програв» («Агресивний») («Я ОК - Ви не ОК») - позбавлення від взаємодї: «Дитяча позиція». Оборонна позиція. Намагання «піднятися» над іншими людьми. При цьому інші люди будуть сприймати цю людину як агресивну, байдужу та гнітючу.

«Той, щэо програв - Той, що програв» («Байдужий») («Я не ОК - Ви не ОК») невключення у взаємодію: «Марна позиція». Людина вважає весь світ та інших людей невдахами, так само, як і себе саму. В неї недбале ставлення до більшості життєвих починань. Для неї «подарунків не існує».

Таким чином, за допомогою опитувальника Дж. Хей (2020) «Вікна у світ» ми плануємо дослідити поведінкову стратегію жінок, яка основана на аналізі життєвої позиції та показує ставлення до себе та інших.

Перейдемо до аналізу методики для вивчення особистісних стилів взаємодї̈ з іншими людьми.

Для дослідження особистісних стилів взаємодії 3 іншими людьми доцільним $є$ використання опитувальника Дж. Хей (2020) «Особистісні стилі».

Опитувальник «Особистісні стилі» був розроблений Дж. Хей (2020) на основі концепції «Его-станів» 3 використанням «Функціональної моделі станів «Я».

Концепція «Его-станів» була розроблена Е. Берном (1999) як модель особистості, яка заснована на станах «Я», які можуть бути змодельовані у структурному і функціональному плані.

Структурна модель «Его-станів» показує, що являє собою кожний зі станів «Я» (Структура = «Що?»= Зміст). Функціональна модель виявляє низку різновидів основних «станів Я» показує, як люди їх використовують (Функція = «Як?» = Зміст) (Стюарт, \& Джойнс, 1996).

Кожному зі станів «Я» відповідають відповідні думки, відчуття та поведінка, які проявляються у взаємодії з іншими людьми. Функціональна модель «Его-станів» має п’ять різновидів станів «Я»: «Батько - Контролер»; «Батько - Вихователь»; «Функціональний Дорослий»; «Природна Дитина»; «Адаптивна Дитина».

Опитувальник Дж. Хей (2020) «Особистісні стилі» містить 40 тверджень, які необхідно оцінити за шкалою: повністю незгодний; частково згодний; цілком згодний; повністю згодний. Після обробки даних отримані результати пропонується намалювати у вигляді гістограми за кожною шкалою, на основі сумарних оцінок. Таким чином, можна отримати особистісний профіль людини і дослідити особистісні стилі взаємодії (поведінкові Его-стани).

«Батько - Контролер» - позитивна сторона цього особистісного стилю: встановлення 
правил взаємодії, особистісних кордонів, твердість, рішучість, контроль виконання домовленостей. Негативна сторона - «командування» та «придушення» інших людей. Ставлення до інших, як до «дітей».

«Батько - Вихователь» - піклування про інших і самого себе, уважність, схильність допомагати іншим. Надмірне занурення у цей стан робить людину нав'язливою, 3 гіперопікаючою поведінкою. Така людина позбавляю іншу людину можливості самостійно рости і розвиватися.

«Функиіональний Дорослий» - логічне мислення, розум, бачення причинно-наслідкових зв'язків, розв'язання проблем та прийняття рішень, аналіз «тут і зараз». Надмірне використання цього «Его-стану» робить людину нудною і занадто логічною. Така людина аналізує все занадто серйозно.

«Природна Дитина» - під впливом цього «Его-стану» людина відчуває свої потреби і проявляє справжні почуття, наповнена творчою енергією. Часто діє імпульсивно. Проявляє відчуття радості, захоплення та дружелюбність. Але надмірне перебування у стані «Природної (вільної) Дитини» може бути розцінене іншими людьми як несерйозність та надмірна емоційність.

«Адаптивна Дитина» - така людина швидко пристосовується до вимог навколишнього середовища, вона привітлива і знає як поводити себе у суспільстві.

Людина поводиться «як потрібно», а не «як хочеться». Якщо занадто захопитися цим поведінковим стилем, то можна відчути відсутність свободи і неможливість отримати бажане. Така людина в очах оточення часто виглядає невпевненою в собі.

Отже, опитувальник Дж. Хей (2020) «Особистісні стилі», який ми застосовуємо в комплексі методик нашого дослідження, призначений для дослідження особистісних стилів взаємодії жінок з іншими людьми.

Проведемо далі аналіз методики для вивчення стилів поведінки у професійній діяльності. Для дослідження стилів поведінки у професійній діяльності буде використаний опитувальник Дж. Хей «Робочі стилі» (Дж. Хей, 2020).

В основі опитувальника «Робочі стилі» Дж. Хей (2020) лежить концепція драйверної поведінки Т. Кейлера (Дж. Хей, 2020).

Поняття директивної поведінки (драйверу) було введено Т. Кейлером (1974) на основі ідеї Е. Берна (1999) про те, що сценарій може програватись протягом коротких проміжків часу. Драйвер - це характерний набір поведінкових реакцій, що розгортаються у часовому проміжку до декількох секунд (Стюарт, \& Джойнс, 1996). 3 роками ця концепція перетворилася на простий набір 3 п’яти характерних стилів поведінки. Їх назвали драйверами, щоб підкреслити їхній «компульсивний» і нав'язливий початок, особливо коли людина перебуває у стресі. Драйвери - це несвідомі спроби поводитися так, щоб отримати визнання іншими, вони також $\epsilon$ запрограмованими реакціями на послання, які людина отримала від значущих людей в минулому (Дж. Хей, 2020).

Драйвери отримали назву у відповідності до своїх характеристик:

«Будь досконалим» («Be perfect»), «Радуй інших» («Please others»), «Намагайся» («Try hard»), «Будь сильним» («Be strong»), «Поспішай» («Наarry»). Більш за все ці драйвери проявляються у поведінці, кожна людина використовує їх протягом життя не тільки як несвідомі моделі сценарної поведінки, а і як «Робочі стилі».

Отже, існує п'ять «Робочих стилів».

«Будь досконалим (кращим)»- людям з цим провідним драйвером притаманні такі риси, як методичність, надійність, точність. Їм властиве прагнення до високих стандартів виконання будь-якої діяльності. Саме через ці стандарти, які $є$ зазвичай завищеними, у них можуть виникати конфлікти з оточуючими. Стосовно себе ці люди також висувають занадто високі вимоги: якщо вони не змогли зробити щось «бездоганно», то досить сильно дорікають собі за власні помилки. Через бажання зробити якнайкраще такі люди можуть зривати строки 
виконання роботи: хочуть щось доробити, покращити тощо. У результаті робота виконується невчасно. Для людини, що має цей драйвер за головний, важливо бути кращою за інших. Тому вона і висуває до себе такі високі вимоги: я можу бути кращою лише тоді, коли буду виконувати бездоганно свою роботу (доручення, хобі, навчання тощо). Для таких людей властиве планування своєї діяльності, але ці плани не завжди втілюються у життя як такі, що не відповідають завищеним стандартам.

«Радуй інших» - для людини, у якої даний драйвер є головним, властиве прагнення до того, щоб навколо все було спокійно, добре, безконфліктно. Провідною детермінантою для цього драйверу є бажання подобатись іншим, причому часто за будь-яку ціну, навіть за рахунок знецінювання власних переживань та прагнень. Поведінка таких людей обумовлена пошуком підтримки та схвалення з боку оточуючих. Вони не просять про допомогу чи задоволення власних потреб у оточуючих, через очікування, що оточуючі мають самостійно здогадатись, чого вони насправді бажають. Такі люди спрямовані на надання допомоги іншим, часто забуваючи про власні потреби. Провідною потребою для людини із драйвером «Подобайся іншим» є спілкування. Саме в спілкуванні вони можуть отримувати «психологічне визнання» своєї особистості.

«Будь сильним» - людина, котра має цей драйвер, демонструє такі риси, як: раціональність, інтегративність, чіткість у виконанні завдань, силу, витривалість. Вона працює у напруженому графіку, використовуючи всю свою витривалість. Через такий спосіб роботи у неї може виникати стрес, фізичне перевантаження. Також проявом цього драйверу є «заборона» на почуття: власні та почуття інших людей. Головним для неї $є$ виконання роботи, навіть ціною фізичного виснаження. Ігнорування власного тіла і тілесних відчуттів може призвести до виникнення психосоматичних захворювань. Людина з цим драйвером не любить просити про допомогу, оскільки розглядає це як прояв слабкості, що є неприпустимим для цього драйверу.

«Намагайся» - для людини, що має даний драйвер, провідним є здійснення дій, вчинків, які вимагають від особистості значних «енергетичних» зусиль. При здійсненні певної діяльності така людина буде намагатись стовідсотково використовувати свій ресурс. Їм подобаються нові незнайомі завдання. На початку нової роботи вони дуже енергійні, активно включаються в роботу, але через деякий час, якщо відсутня новизна у роботі, втрачають інтерес до неї. Активність знижується, і вони починають шукати щось інше, нове, оригінальніше. Таким чином, в арсеналі таких людей є багато розпочатих справ, але лише незначна їх частина доводиться до логічного завершення. Найбільш яскраво це проявляється на рівні хобі: фактично не має такого заняття, яке продовжувалося б тривалий час.

«Поспішай» - проявом цієї драйверної поведінки є постійне «поспішання» та високий рівень «зайнятості» людини; така особистість завжди перебуває у активному русі, здійсненні певних дій, планів тощо. Люди із цим драйвером швидко думають та приймають рішення. Можуть запізнюватись на ділові зустрічі, роботу. Вони погано слухають оточуючих, часто закінчуючи речення за свого співрозмовника. Це не люди деталей, вони мислять «глобально». Швидкий темп виконання роботи та бажання здійснювати якомога більше одночасно можуть призвести до виникнення стресу. Через велику завантаженість такі люди не встигають виконати всю роботу, припускаються помилок у процесі ії̈ виконання.

Опитувальник Дж. Хей (2020) «Робочі стилі» має 25 тверджень, які пропонується оцінити по шкалі від 0 до 8 , де: 8 - повна згода, а 0 - повна незгода. Після обробки даних результати пропонується намалювати у вигляді гістограми за 5 шкалами: «Поспішай», «Будь досконалим», «Радуй інших», «Намагайся», «Будь сильним».

Опитувальник Дж. Хей (2020) «Робочі стилі» у запропонованому нами комплексі методик призначений для дослідження стилів поведінки жінок у професійній діяльності.

Далі розглянемо третю групу методик, у яку увійшли методики для вивчення соціально-демографічних, організаційно-професійних, соціально-економічних та гендерних чинників, які впливають на ставлення жінок до грошей. 
Першою проаналізуємо методику для вивчення гендерного типу особистості. Для дослідження гендерного типу особистості буде використана методика С. Бем (модифікований варіант О.Г. Лопухової «Маскулінність, фемінність та гендерний тип особистості» (О. Лопухіна, 2013).

Методика С. Бем «Bem Sex Role Inventory» призначена для вимірювання рівня маскулінності та фемінності, а також для визначення психологічної статі особистості. Концептуальною основою оригінальної методики є теорія андрогін. Підставою теорії андрогін стала ідея А. Константінопль (1973), що фемінність і маскулінність - не протилежні полюси одновимірного континууму, а скоріше незалежні конструкти. Відповідно до теорії андрогін, кожна особистість може володіти і фемінними, і маскулінними характеристиками одночасно, крім того, передбачалося, що ефективність функціонування особистості в будь-який сфері діяльності залежить від здатності проявляти як фемінні, так і маскулінні якості адекватно ситуацій, що виникають, а не обмежувати свою поведінку відповідно до статевої приналежністю. У руслі цих ідей в 1971-1974 pp. С. Бем розробила опитувальник «Веm Sex Role Inventory» (О. Лопухіна, 2013).

Методика С. Бем «Bem Sex Role Inventory» складається з 3 шкал: шкали маскулінності, шкали фемінності та буферної шкали загальнолюдських якостей. В адаптованому варіанті шкали маскулінності та фемінності містять по 14 особистісних якостей, які відображають чоловічі або жіночі характеристики, кількість тверджень було скорочено до 27 (О. Лопухіна, 2013).

Шкала маскулінності складається з наступних характеристик особистості: мужність, вміння самостверджуватися, наполегливість, аналітичність, здатність керувати, готовність ризикувати, домінування, зовнішня стриманість, здатність діяти у якості лідера, сила, сміливість, сила волі, витривалість.

Шкала фемінності містить наступні характеристики: жіночність, поступливість, сором'язливість, схильність до прояву почуттів, ніжність,

співчутливість, м'якість висловлювань, прагнення втішити, чарівність, довірливість, дитяча безпосередність, відсутність різких, грубих висловлювань, краса, терпимість.

Методика дозволяє проаналізувати окремо рівень кожної зі шкал, а також в подальшому визначити психологічну стать особистості. Отже, маскулінна психологічна стать визначається перевагою маскулінних характеристик над фемінними, фемінна психологічна стать характеризується суттєво вищим рівнем фемінності, ніж маскулінності. Маскулінна психологічна стать $є$ варіантом норми для чоловіків, фемінна - для жінок, а повна невідповідність психологічної статі біологічній є ознакою крос-гендерності особистості.

Андрогінна психологічна стать передбачає, що рівень і маскулінних, і фемінних характеристик буде високим. Цей тип психологічної статі сьогодні вважається нормою як для чоловіків, так і для жінок.

Недиференщійована психологічна стать характеризується низьким рівнем прояву як маскулінності, так і фемінності та $є$ ознакою психопатології або крос-культурних відмінностей у розумінні маскулінності та фемінності.

Методика С. Бем (модифікований варіант О. Г. Лопухової) «Маскулінність, фемінність та гендерний тип особистості» в підібраному нами комплексі методик призначена для дослідження гендерного типу особистості.

Розглянемо методики для вивчення соціально-демографічних, організачійно-професійних та сочіально-економічних чинників, які впливають на ставлення жінок до грошей. Для вивчення даної групи чинників планується використання «Анкети-паспортички». До анкети будуть включені питання для дослідження таких характеристик жінок: а) соціальнодемографічних показників жінок (стать, вік, місце проживання, сімейний стан, наявність дітей, кількість дітей та ін.)); б) організаційно-професійних (напрямок професійної діяльності/ відсутність професійної зайнятості, посада в організації, рівень освіти, загальний стаж роботи, 
стаж роботи на посаді та ін.); в) соціально-економічних (соціальне походження, економічний статус сім’ї, рівень доходу та ін.).

Низка досліджень психології грошей показують, що ставлення особистості до грошей перебуває в тісному зв'язку як з психологічними чинниками, так і з соціально-демографічними, організаційно-професійними та соціально-економічними.

Так, дослідження гендерних особливостей ставлення до грошей А. Фермена (1998) показує, що жінки частіше відчувають одержимість грошима, вони більше консервативні у фінансових питаннях та схильні вважати, що вони гірше контролюють власне фінансове становище, ніж чоловіки. Т. Миронова (2012), досліджуючи соціально-демографічні детермінанти, що впливають на процес формування монетарних установок, виявила вплив чинника «місце проживання». Так, проживання на «периферії» впливає на сприйняття грошей як об'єкта, що приносить задоволення, допомагає відчути себе впевнено і вільно. Існують також вікові особливості ставлення до грошей. А. Фернем (1998) виявив, що молоді люди більш схильні використовувати гроші як засіб впливу на інших людей, меншою мірою дбають про фінансову безпеку та менш стривожені питаннями фінансового майбутнього, порівняно 3 особами старшого віку.

Взаємозв'язок монетарних установок 3 рівнем доходу підтверджують результати багатьох зарубіжних і вітчизняних досліджень. П. Вернімонт та С. Фіцпатрік (1972) виявили, що особи з вищим рівнем доходу акцентують свою увагу на можливості використання грошей 3 метою забезпечення матеріального комфорту та безпеки. Одержимість грошима частіше проявляється у людей з нижчим рівням доходу.

Дослідження взаємозв'язку монетарних установок з рівнем освіти особистості показали, що менш освічені люди частіше переживають грошову одержимість та використовують гроші в якості інструменту впливу на інших. Більш освічені особи більше уваги приділяють плануванню власних доходів, витрат та заощаджень (Сімків, 2014). О. Паршак (2020), досліджуючи ставлення персоналу комерційних організацій до грошей виявив, що позитивне ставлення до грошей зростає в міру підвищення рівня освіти та стажу роботи в компанії.

Таким чином, монетарні установки особистості перебувають у тісному взаємозв'язку не тільки 3 психологічними, а i 3 соціально-демографічними, організаційно-професійними та соціально-економічними чинниками.

Анкету-«паспортичку» нами було включено до комплексу методик з метою дослідження соціально- демографічних, організаційно-професійних та соціально-економічних чинників, які впливають на ставлення жінок до грошей.

\section{Висновки:}

1. У процесі дослідження визначено комплекс методик для дослідження особистіснопрофесійних стилів поведінки як чинника ставлення жінок до грошей.

2. Комплекс включає три групи методик: для вивчення ставлення жінок до грошей; методики для дослідження особистісно-професійних стилів жінок; методики для вивчення гендерних, соціально-демографічних, організаційно-професійних, соціально-економічних характеристик жінок, які впливають на їх ставлення до грошей.

3. У першій групі виділено методики для: визначення монетарних установок особистості; дослідження переважаючого типу ставлення особистості до грошей; вивчення соціально-психологічних установок особистості у сфері мотивацій і потреб.

4. До складу другої групи входять методики для: дослідження життєвої позиції особистості; вивчення особистісних стилів взаємодії з іншими людьми; аналізу стилів поведінки у професійній діяльності.

5. До третьої групи увійшли: методики для вивчення гендерного типу жінок; аналізу соціально-демографічних, організаційно-професійних чинників та соціально-економічних чинників, які впливають на ставлення жінок до грошей.

6. Використання комплексу вказаних методик дає можливість, на наш погляд, 
емпірично дослідити особистісно-професійних стилі поведінки як чинника ставлення жінок до грошей.

Перспективи подальших досліджень. Перспективи дослідження ми вбачаємо у розробці тренінгової програми для жінок, яка спрямована на формування у жінок усвідомленого ставлення до грошей. Тренінгова програма може бути впроваджена для психологічної підготовки жінок, які працюють в державних та комерційних організаціях, $\epsilon$ членами громадських організацій.

\section{Література}

1. Берн, Э. (1999). Игры, в которые играют люди: Психология человеческих взаимоотношений; Люди, которые играют в игры: Психология человеческой судьбы. Москва: ФАИР-ПРЕСС.

2. Горностай, П. (2007). Личность и роль: Ролевой подход в сочииальной психологии личности. Киев: Интерпресс ЛТД.

3. Зубіашвілі, І. К. (2009). Ставлення до грошей як фактор економічної соичіалізації старшокласників. Автореф. дис. канд. психол. наук. Київ.

4. Зубіашвілі, І. К. (2007). Проблема монетарних відносин особистісно зрілих людей у сучасній психології. Наукові записки Інституту психологї ім. Г. С. Костюка АПН України, 32, 116-123.

5. Карамушка, Л. М., \& Ходакевич, О. Г. (2017). Психологічні особливості ставлення студентської молоді до грошей: монографія. Київ: КНЕУ.

6. Карамушка, Л. М., \& Ходакевич, О. Г. (2012). Оцінка студентами ролі грошей у їх життєдіяльності. Актуальні проблеми психології: зб. наук. пр. Інституту психології імені Г. С. Костюка АПН України, 1, 35, 111-117.

7. Костіна, Т. О. (2011). Дослідження провідного драйверу особистості юнацького віку. Актуальні проблеми nсихологї̈: зб. наук. пр. Інституту психології імені Г. С. Костюка АПН України, 1, 57, 92-100.

8. Лопухина, О. Г. (2013). Опросник «Маскулинность, феминность и гендерный тип личности» (Российский аналог «Bem Sex Role Inventory»).

Вопросы психологии, 1, 147-154.

9. Миронова, Т. Ю. (2012). Некоторые факторы отношения подростков и юношей к деньгам. Известия Саратовского университета. Новая серия. Философия. Психология. Педагогика, 12, 3, 74-78.

10. Паршак, О. I. (2018). Методики для дослідження ставлення до грошей персоналу комерційних організацій. Організаційна психологія. Економічна психологія, 2 (13), 93-99.

11. Паршак, О. I. (2020). Оцінка персоналом комерційних організацій ролі грошей у його життєдіяльності: зв'язок iз психологічними та організаційно-функціональними характеристиками організацій. Актуальні проблеми психологї̈: зб. наук. пр. Інституту психології імені Г. С. Костюка АПН України, 1, 57, 92-100.

12. Сімків М. В. (2011). Адаптація модифікованого україномовного варіанта методики Т.Танга «Шкала грошової етики» (ШГЕ). Практична психологія та соиіальна робота, 2, 22-26.

13. Сімків, М. В. (2012). Модифікований варіант методики А. Фернема «Шкала грошових уявлень та поведінки». Освіта регіону, 2, 295-301.

14. Сімків, М. В. (2012). Суб’єктивний контроль як чинник ставлення до грошей у жінок. Проблеми загальної та педагогічної психології: зб. наук. пр. Інституту психології імені Г. С. Костюка АПН України, 12, 1, 541-551.

15. Сімків, М. В. (2014). Соціально-демографічні чинники монетарних настановлень молоді. Актуальні проблеми nсихологї: зб. наук. пр. Інституту психології імені Г. С. Костюка АПН України, 10, 26, 666-678.

16. Стюарт, Я., \& Джойнс, В. (1996). Транзактный анализ. Санкт-Петербург: Социально-психологический центр.

17. Харрис, Т. Э. (2020). Я-O’Кeŭ, Tbl-O’Кей. Москва: Академический проект.

18. Хей, Дж. (2020). Транзактний анализ для тренеров. Санкт-Петербург: Метанойя.

19. Constantinople, A. (1973). Masculinity-femininity: An exception to a famous dictum. Psychol. Bull, 80, $389-407$.

20. Furnham, A., \& Argyle, M. (1998). The psychology of money. New York: Routledge.

21. Kahler, T., \& Capers H. (1974). The Miniscript. Transactional Analysis Journal, 4, 1, $26-42$.

22. Tang, T. (1993). The meaning of money: extension and exploration of the money ethic scale. Journal of Organizational Behavior, 14, 93-109.

23. Wernimont, P. F. \& Fitzpatrick, S. (1972). The meaning of money. Journal of Applied Psychology, 56, $218-226$.

\section{References}

1. Berne, E. (1999). Igry, v kotorye igrajut ljudi: Psihologija chelovecheskih vzaimootnoshenij; Ljudi, kotorye igrajut v igry: Psihologija chelovecheskoj sudby [Games people play: the psychology of human relationships; People who play games: the psychology of human destiny]. Moscow: FAIR-PRESS [in Russian].

2. Gornostaj, P. (2007). Lichnost i rol: Rolevoj podhod v socialnoj psihologii lichnosti [Personality and role: Role approach in social psychology of personality]. Kiev: Interpress LTD [in Russian]. 
3. Zubiashvili, I. K. (2009). Stavlennia do hroshei yak faktor ekonomichnoi sotsializatsii starshoklasnykiv [Attitude towards money as a high school students' economic socialization factor]. Kyiv [in Ukrainian].

4. Zubiashvili, I. K. (2007). Problema monetarnykh vidnosyn osobystisno zrilykh liudei u suchasnii psykholohii [The problem of monetary relations between personally mature people in modern psychology]. Naukovi zapysky Instytutu psykholohii im. H. S. Kostiuka APN Ukrainy, 32, 116-123 [in Ukrainian].

5. Karamushka, L. M., \& Khodakevych, O. H. (2017). Psykholohichni osoblyvosti stavlennia studentskoi molodi do hroshei [Psychological features of students' attitude towards money: a monograph]. Kyiv: KNEU [in Ukrainian].

6. Karamushka, L. M., \& Khodakevych, O. H. (2012). Otsinka studentamy roli hroshei u yikh zhyttiediialnosti [Students' assessment of the role of money in their lives]. Aktualni problemy psykholohii: zb. nauk. pr. Instytutu psykholohii imeni H. S. Kostiuka APN Ukrainy, 1, 35, 111-117 [in Ukrainian].

7. Kostina, T. O. (2011). Doslidzhennia providnoho draiveru osobystosti yunatskoho viku [A study of the leading driver of adolescence]. Aktualni problemy psykholohii: zb. nauk. pr. Instytutu psykholohii imeni H. S. Kostiuka APN Ukrainy, 1, 57, 92-100 [in Ukrainian].

8. Lopuhina, O. G. (2013). Oprosnik «Maskulinnost, feminnost i gendernyj tip lichnosti» (Rossijskij analog «Bem Sex Role Inventory») [Questionnaire "Masculinity, femininity and gender type of personality" (Russian analogue of the Bem Sex Role Inventory)]. Voprosy psihologii, 1, 147-154 [in Russian].

9. Mironova, T. Ju. (2012). Nekotorye faktory otnoshenija podrostkov i junoshej k dengam [Some factors in adolescents and young people's attitude towards money]. Izvestija Saratovskogo universiteta. Novaja serija. Filosofija. Psihologija. Pedagogika, 12, 3, 74-78 [in Russian].

10. Parshak, O. I. (2018). Metodyky dlia doslidzhennia stavlennia do hroshei personalu komertsiinykh orhanizatsii [Tools for studying commercial organization staff's attitude towards money]. Orhanizatsiina psykholohiia. Ekonomichna psykholohiia, 2 (13), 93-99 [in Ukrainian].

11. Parshak, O. I. (2020). Otsinka personalom komertsiinykh orhanizatsii roli hroshei u yoho zhyttiediialnosti: zviazok iz psykholohichnymy ta orhanizatsiino-funktsionalnymy kharakterystykamy orhanizatsii [Staff's assessment of the role of money in the life of commercial organizations: the relationship with the organizations' psychological, organizational and functional characteristics]. Aktualni problemy psykholohii: zb. nauk. pr. Instytutu psykholohii imeni H. S. Kostiuka APN Ukrainy, 1, 57, 92-100 [in Ukrainian].

12. Simkiv M. V. (2011). Adaptatsiia modyfikovanoho ukrainomovnoho varianta metodyky T.Tanha «Shkala hroshovoi etyky» (ShHE) [Adaptation of the modified Ukrainian version of T. Tang's Monetary Ethics Scale (MES)]. Praktychna psykholohiia ta sotsialna robota, 2, 22-26 [in Ukrainian].

13. Simkiv, M. V. (2012). Modyfikovanyi variant metodyky A. Fernema «Shkala hroshovykh uiavlen ta povedinky» [Modified version of A. Fernem's Monetary Ideas and Behavior Scale]. Osvita rehionu, 2, 295-301 [in Ukrainian].

14. Simkiv, M. V. (2012). Subiektyvnyi kontrol yak chynnyk stavlennia do hroshei u zhinok [Subjective control as a factor in women's attitudes to money]. Problemy zahalnoi ta pedahohichnoi psykholohii: zb. nauk. pr. Instytutu psykholohii imeni H. S. Kostiuka APN Ukrainy, 12, 1, 541-551 [in Ukrainian].

15. Simkiv, M. V. (2014). Sotsialno-demohrafichni chynnyky monetarnykh nastanovlen molodi [Socio-demographic factors in young people's monetary attitudes]. Aktualni problemy psykholohii: zb. nauk. pr. Instytutu psykholohii imeni H. S. Kostiuka APN Ukrainy, 10, 26, 666-678 [in Ukrainian].

16. Stjuart, Ja., \& Dzhojns, V. (1996). Tranzaktnyj analiz [Transactional analysis]. Sankt-Peterburg: Socialnopsihologicheskij centr [in Russian].

17. Harris, T. Je. (2020). Ja-O'Kej, Ty-O'Kej [I'm OK, you're OK]. Moskva: Akademicheskij proekt [in Russian]. 18. Hej, Dzh. (2020). Tranzaktnij analiz dlja trenerov [Transactional analysis for coaches]. Sankt-Petersburg: Metanoja [in Russian].

19. Constantinople, A. (1973). Masculinity-femininity: An exception to a famous dictum. Psychol. Bull, 80, $389-407$.

20. Furnham, A., \& Argyle, M. (1998). The psychology of money. New York: Routledge.

21. Kahler, T., \& Capers H. (1974). The Miniscript. Transactional Analysis Journal, 4, 1, $26-42$.

22. Tang, T. (1993). The meaning of money: extension and exploration of the money ethic scale. Journal of Organizational Behavior, 14, 93-109.

23. Wernimont, P. F. \& Fitzpatrick, S. (1972). The meaning of money. Journal of Applied Psychology, 56, $218-226$.

\section{Nataliia Klymenko. A set of instruments to study women's personal and professional behavioral styles as factors in their attitudes towards money. \\ Introduction. In order to study the impact of women's personal and professional behavioral styles on} their attitudes towards money, which is an important problem in the context of women's economic socialization and inclusion in social and professional life, researchers need, in particular, special research methods and instruments.

Aim. To develop a set of instruments to study women's personal and professional behavioral styles as factors in their attitudes towards money. 
Results. The author has developed a set of instruments, which includes (a) instruments to study monetary attitudes of a person, (b) instruments to study women's personal and professional behavioral styles, and (c) instruments to study gender, socio-demographic, organizational-professional and socio-economic factors behind women's attitudes towards money and personal and professional behavioral styles.

Conclusions. The proposed set of instruments can be used for assessing women's personal and professional behavioral styles as factors in their attitudes to money.

Key words: women's attitude towards money, monetary attitudes of the individual, prevailing attitudes towards money, work-money attitudes, personal and professional behavioral styles, life positions of the individual, personal style of interaction with other people, work behavioral styles, factors behind attitudes towards money, instruments to study attitudes towards money, instruments to study women's personal and professional behavioral styles.

\section{Відомості про автора}

Клименко Наталія Геннадіївна, аспірантка Інституту психології імені Г.С. Костюка НАПН України, м. Київ, Україна. Ukraine.

Klymenko, Nataliia, PhD student, G.S. Kostiuk Institute of psychology of the NAES of Ukraine, Kyiv,

E-mail: nk.psychol@gmail.com

ORCID ID: https://orcid.org/0000-0002-1897-3201

Отримано 2 листопада 2020 р. Рецензовано 19 листопада 2020 р. Прийнято 20 листопада 2020 р.

DOI (Article): https://doi.org/10.31108/2.2020.4.21.7

УДК 159.923

Клочко Алла

\section{ТИПИ МЕНЕДЖЕРІВ ОСВІТНІХ ОРГАНІЗАЦІЙ ЗА ЇХНІМ СТАВЛЕННЯМ ДО ЗМІН: ЗВ'ЯЗОК ІЗ ПСИХОЛОГІЧНИМИ ХАРАКТЕРИСТИКАМИ ОРГАНІЗАЦЇ̈}

\footnotetext{
Клочко Алла. Типи менеджерів освітніх організацій за їхнім ставленням до змін: зв'язок із характеристиками організації.

Вступ. Модернізація освіти актуалізує проблему врахування психологічних характеристик освітніх організацій, які можуть сприяти розвитку інновачійних стилів управління, притаманним певним типам менеджерів освіти.
}

Мета дослідження: проаналізувати зв'язок між психологічними характеристиками організації і типами менеджерів освітніх організацій за їхнім ставленням до змін.

Методи дослідження. Опитувальники «Як Ви ставитесь до змін?» К. Фрайлінгера та I. Фішера, «Як розвивається Ваша організачія?» В. Зігерта, Л. Ланге, (модифікачія Л.М. Карамушки), методика «Очінка задоволення роботою» В.О. Розанової, шкала суб'єктивного благополуччя Г. ПеруеБаду (адаптація М.В. Соколової), авторська анкета-паспортичка.

Результати дослідження. У статті на основі емпіричного дослідження встановлено позитивні та негативні статистично значущуі зв'язки між трьома групами психологічних характеристик організації (внутрішньоорганізаційними; які відображають взаємодію організації та персоналу; організаційно-функціональними) $і$ окремими типами менеджерів освітніх організацій за їхнім ставленням до змін.

Висновки. Врахування виявлених закономірностей може сприяти психологічному забезпеченню 